\title{
Intercropping system of tropical leguminous species and Eucalyptus camaldulensis, inoculated with rhizobia and/or mycorrhizal fungi in semiarid Brazil
}

\author{
Marcela C. Pagano • Marta N. Cabello • \\ Antonio F. Bellote · Nadja M. Sá • \\ Maria Rita Scotti
}

Received: 2 January 2007 / Accepted: 10 September 2008/Published online: 26 September 2008

(C) Springer Science+Business Media B.V. 2008

\begin{abstract}
For the purpose of reforestation and wood supply the leguminous tree Anadenanthera peregrina, a native species, was intercropped with Eucalyptus camaldulensis in a degraded semiarid area of Brazil. Single and mixed stands of these species were inoculated with Rhizobium and/or arbuscular mycorrhizal fungi (AMF). The growth of all species in mixed stands did not differ from those cultivated in monoculture and land equivalent ratio (LER) exceeded unity in intercropped plots. Inoculated plants showed greater height and diameter growth and dry matter and nutrient concentration in plants of A. peregrina was higher in inoculated single plots. The distribution, composition and density of AMF species was related to the rhizosphere effect of plant
\end{abstract}

M. C. Pagano · N. M. Sá · M. R. Scotti $(\bowtie)$

Department of Botany, Institute of Biological Sciences, Federal University of Minas Gerais, Av. Antônio Carlos, 6627, Pampulha, CEP 31270-901 Belo Horizonte, MG, Brazil

e-mail: scottimuzzi@superig.com.br

M. C. Pagano

e-mail: marpagano@gmail.com

M. N. Cabello

Institute of Biological Sciences, National University of

La Plata, La Plata, Argentina

e-mail: mcabello@netverk.com.ar

A. F. Bellote

Embrapa Forestry, Estrada da Ribeira, km 111,

Caixa Postal 319, Colombo, PR 83411-000, Brazil species. The intercropped model where all the plants were inoculated achieved soil AMF diversity patterns similar to those of the preserved area and showed also higher soil organic matter, nutrient content as well as a reduction in soil macroporosity. This model of intercropping may be considered as an efficient system for reforestation under semiarid conditions.

Keywords Anadenanthera peregrina $\cdot$ Arbuscular mycorrhizal fungi - Eucalyptus camaldulensis . Nitrogen fixation - Land equivalent ratio

\section{Introduction}

One of the most important irrigation programs in Brazil is the Jaíba Project, established in the semiarid area of Minas Gerais State to improve agricultural production and the economic and social development of the region. In this project the demand for wood by farmers has become a continuous threat to the preserved area, one of the largest protected areas (Rizzini 1997).

The current demand for wood is not met by forest restoration efforts, revealing a need for an effective project of wood and energy provision for the local populations. Plantations of Eucalyptus species play a major role in Brazilian wood production. However, in dry climates, there are legal restrictions on the use of monocultures of Eucalyptus. Mixed-species plantations are an alternative to re-vegetation with native species (Rao et al. 1997), since both Eucalyptus plants 
and leguminous trees can provide wood while the latter can also improve soil fertility (Marques et al. 2003; Scotti and Correa 2004). Work in regions such as Australia (May and Attiwill 2003) and Brazil (Santiago et al. 2002) have shown the advantages of intercropping systems using legumes and Eucalyptus for increasing plant growth and improving soil fertility. Legume species are generally chosen because of their ability to develop symbiotic associations with both rhizobial bacteria and arbuscular mycorrhizal fungi (AMF). Bacteria of the genus Rhizobium or Bradyrhizobium are capable of fixing atmospheric nitrogen in root nodules. On the other hand, root access to nutrients, especially phosphate, can be enhanced by association with AMF. Dual inoculation significantly improves plant survival, mineral nutrition and water absorption during drought conditions (Marques et al. 2001), as well as enhancing decomposition of soil organic matter (Hodge et al. 2001).

One way to assess the benefits of growing two or more crops together, or intercropping, is to measure productivity using the Land Equivalent Ratio (LER), which is useful as a first approach to help the farmer to decide whether agroforestry is a worthwhile solution (Mead and Willey 1980). The advantages of intercropping have been demonstrated in numerous systems in the tropics (Ghosh 2004). The benefits of intercropping include improvement of soil fertility (because of greater biomass production, nutrient cycling and biological nitrogen fixation), soil physical conditions (because of organic matter aggregation, humic acid and glomalin production, and root activity), and soil erosion control. A disadvantage, however, is the fact that there may be competition among species and therefore reduced yields of the system (Ritz and Young 2004).

The ecological principles that define competitive interaction among plants have not been sufficiently well determined to establish an operational approach. The influence of tree components on other components is quantifiable through different responses including allelopathy (Rao et al. 1997). The Eucalyptus species, considered notorious allelopathic trees and one of the most commonly studied groups of plants, are used in afforestation models all over the world (May and Ash 1990). The aims of this study were: (1) to examine the effect of E. camaldulensis on the growth of A. peregrina, a native species, in mixed stands under semiarid conditions; (2) to evaluate the effect of inoculation with rhizobia and/ or arbuscular mycorrhiza on plant growth, as part of a strategy for re-vegetation of a degraded semiarid area; and (3) to evaluate the benefits of growing intercropped native species and E. camaldulensis plants, in relation to monoculture through the LER.

\section{Materials and methods}

Study site

The study area is located in the north of Minas Gerais State in Brazil included in the semiarid region $\left(15^{\circ} 09^{\prime} 03^{\prime \prime} \mathrm{S} 43^{\circ} 49^{\prime} 26^{\prime \prime} \mathrm{W}\right)$, characterized by annual pluviometric rates of $800 \mathrm{~mm}$ concentrated in the spring-summer months from November to January. The Forest Reserve is one of the largest protected areas of woody caatinga with prominent vegetation composed by xerophytic trees and shrubs having a total density of $1,029.28$ trees per hectare reaching heights of 10-25 m. When the woody caatinga is cut the area is invaded by a dense community of interlaced shrubs, a disturbed vegetation known as Carrasco, with coriaceous leaves, attaining heights of 2-5 m (Rizzini 1997).

\section{Species selection}

Native species of woody caatinga were selected to be cultivated in mixed plantation due to their ability to grow in presence of essential oils from Eucalyptus grandis and E. camaldulensis in vitro (data not shown) as described in Duarte et al. (2006). This paper reports on the intercropping of Anadenanthera peregrina (L.) Spegazzini (Mimosoideae), Myracrodruon urundeuva Fr. Allem. (Anacardiaceae) and Eucalyptus camaldulensis. Anadenanthera peregrina was also selected as one component of mixed forest due to the fact that it associates symbiotically with rhizobia and AMF (Scotti and Correa 2004) and its wood is moderately dense, making it suitable for furniture manufacturing. On the other hand, M. urundeuva is classified within the near threatened category of the official Brazilian endangered species list. The main factors which threaten its survival are uncontrolled exploitation due to their great economic value of wood and medicinal properties. Both species may be considered biomass producers. 
Soil analysis

Soil samples were collected from the top $20 \mathrm{~cm}$. Three mixed sub-samples/plot were collected in experimental area using a transversal transect of $21 \mathrm{~m} /$ plot, thus constituting three samples/plot or nine samples/treatment or 81 samples in total (see field experimental design). A similar transect of $100 \mathrm{~m}$ was made in two adjacent fields, one in an area with disturbed vegetation and another one in the forest reserve (preserved area). Ten soil samples were collected in each area. The collected soil samples were sieved through a $2 \mathrm{~mm}$ mesh. The samples were analyzed for chemical and physical properties by the Brazilian Agricultural Research Corporation (EMBRAPA 1979). The texture of the soil in the experimental area was identified as sandy soil with the following composition: coarse sand $=51 \%$, fine sand $=35 \%$, silt $=1.0 \%$, clay $=13 \%$.

Inoculants

Plants were inoculated with rhizobia and/or mycorrhizal fungi. The rhizobia strain BHCB-A10 was previously isolated from nodules of A. peregrina at the Jaíba Project forest reserve and previously screened for its effectiveness under greenhouse, nursery and field conditions (Scotti and Correa 2004). The bacterial inocula were provided at $1 \mathrm{ml}$ per pot $\left(10^{7} \mathrm{cfu} / \mathrm{ml}\right)$ according to Somasegaran and Hoben (1985). The AMF used were Gigaspora margarita, Scutellospora heterogama and Glomus brohultii from the ICB-UFMG laboratory collection. Endomycorrhizal inoculation was accomplished by placing $1 \mathrm{ml}$ of suspension composed of 50 spores of each AMF species and 150 spores/ml into each pot.

Field experimental design

The experimental site (1.5 ha) was cleared of invasive carrasco plants. Anadenanthera peregrina, Eucalyptus camaldulensis and Myracrodruon urundeuva seedlings were transplanted during the rainy season using a randomized block design with nine treatments. There were three blocks, each composed of five plots of $432 \mathrm{~m}^{2}(18 \times 24 \mathrm{~m})$ with single species plantations and 48 plants/plot and 4 plots of $720 \mathrm{~m}^{2}(30 \times 24 \mathrm{~m})$ with 80 plants/plot, where each row was cultivated with one of the three species at $3 \times 3 \mathrm{~m}$ spacing. Excluding the buffer rows there was a useful area of 24 plants/species in single species plots and 16 plants/species in mixed plots.

The treatments were: $1-$ Monoculture of A. peregrina plus complete $(100 \%)$ fertilization; 2-Monoculture of A. peregrina inoculated with Rhizobium and AMF plus $80 \%$ fertilization; 3-Monoculture of E. camaldulensis with complete fertilization; 4Monoculture of E. camaldulensis inoculated with AMF plus $80 \%$ fertilization; 5-Monoculture of Myracrodruon urundeuva plus complete fertilization; 6-Mixed plantation of E. camaldulensis, A. peregrina and $M$. urundeuva plus complete fertilization; 7-Mixed plantation of A. peregrina inoculated with Rhizobium and AMF plus $80 \%$ fertilization and E. camaldulensis and M. urundeuva with complete fertilization; 8-Mixed plantation of E. camaldulensis inoculated with AMF plus $80 \%$ fertilization, A. peregrina and $M$. urundeuva plus complete fertilization; 9-Mixed plantation of E. camaldulensis inoculated with $\mathrm{AMF}$ and $80 \%$ fertilization, A. peregrina inoculated with rhizobia plus AMF plus $80 \%$ fertilization and M. urundeuva with complete fertilization. Complete fertilization consisted of triple superphosphate (500 kg ha $\left.{ }^{-1}\right)$, KCL (382 $\left.\mathrm{kg} \mathrm{ha}^{-1}\right), \mathrm{MgSO}_{4} 7 \mathrm{H}_{2} \mathrm{O}$ : $50 \mathrm{~kg} \mathrm{ha}^{-1}, \mathrm{ZnSO}_{4} 7 \mathrm{H}_{2} \mathrm{O}: 46.8 \mathrm{~kg} \mathrm{ha}^{-1}, \mathrm{Mo}_{7} \mathrm{O}_{2} 4 \mathrm{H}_{2} \mathrm{O}$ : $1.76 \mathrm{~kg} \mathrm{ha}^{-1}$, urea: $222 \mathrm{~kg} \mathrm{ha}^{-1}$ according to Somasegaran and Hoben (1985) and was used at seedling transplanting.

Analysis of plant growth under field conditions

Height and diameter of all plants of A. peregrina and E. camaldulensis were measured over 2 years. After that time, three $A$. peregrina plants were sampled from monocultures with and without inoculation for an estimate of leaf, branch and stem dry matter. The branches were separated from the trunk, all the leaves were collected and fresh weight was recorded. The samples were dried in a chamber with air circulation at $60^{\circ} \mathrm{C}$ until constant weight was achieved. Finally, the samples were weighed in order to determine dry weight. Composite samples (100 g) of different physiological states (young, mature and old) were used to estimate total dry weight according to the formula

$T D W=T F W \times\left(D W_{s} / F W_{s}\right)$, 
where $T D W$, total dry weight $(\mathrm{g}) ; T F W$, total fresh weight $(\mathrm{g}) ; D W_{s}$, sample dry weight $(\mathrm{g}) ; F W_{s}$, sample fresh weight $(\mathrm{g})$.

Macronutrient quantification in above-ground biomass (EMBRAPA 1979) was calculated on the basis of nutrient concentrations per biomass production/ hectare $\left(\mathrm{g} \mathrm{kg}^{-1}\right)$. The sum of the values for each component provided the total nutrient content $\left(\mathrm{kg} \mathrm{ha}^{-1}\right)$ of above-ground biomass. To determine the significance of treatment differences the data was subjected to analysis of variance and $F$-test. The significance of mean differences was detected using the Tukey test at 5\% probability level.

Mycorrhizal and rhizobial efficiency was calculated using the formula:

$M E=\{(M-N M) / N M\} \times 100$,

where $M$ and $N M$ represent dry matter production by inoculated and non-inoculated plants (Somasegaran and Hoben 1985). The data were compared by the Tukey test.

\section{AM fungal spores}

Arbuscular mycorrhizal spores were recovered from soil samples of each treatment in the field, separated by wet sieving (Gerdemann and Nicolson 1963), decanting and sucrose centrifugation (Walker et al. 1982), and the analyzed data were expressed as the number of spores/100 $\mathrm{g}$ of dry soil. Spores were identified by species according to current taxonomic criteria (Schenk and Perez 1988; INVAM; West Virginia, USA, http://invam.caf.wvu.edu). The data were submitted to cluster analysis.

\section{Competition indices}

To compare intercropped and monoculture growth, the LER was used. A LER is an indicator for comparing and estimating the benefit of various ways of managing intercropped plots. It is defined as the land amount equivalent needed to grow both crops or cultures together compared to the amount of land needed to grow a pure stand of each. To calculate the LER, the intercrop yield of one culture is divided by the yield of the pure stand (Mead and Willey 1980). In this study we used diameter and height as yield parameters.
LER $=\left(\right.$ Growth $_{\mathrm{ab}} /$ Growth $\left._{\mathrm{aa}}\right)+\left(\right.$ Growth $_{\mathrm{ba}} /$ Growth $\left._{\mathrm{bb}}\right)$,

where Growth $_{\mathrm{aa}}$ or Growth $\mathrm{bb}_{\mathrm{b}}$ are growth as pure culture and Growth ${ }_{\mathrm{ab}}$ and Growth $_{\mathrm{ba}}$ are growth as intercrops. A LER value greater than 1.0 usually shows that intercropping is advantageous, thus indicating efficiency of the intercropping system over the sole cropping system (Vandermeer 1989). Analysis of variance was performed on LERs values using Oneway ANOVA and the means were compared by the Tukey test $(P \leq 0.001)$.

\section{Results}

Growth and dry matter production of $A$. peregrina and E. camaldulensis plants inoculated with rhizobia and/or mycorrhiza

Under field conditions, height and diameter growth of A. peregrina (Fig. 1a, b) did not differ significantly between single and mixed stands except when uninoculated plants were intercropped with E. camaldulensis that had been inoculated with AMF. E. camaldulensis plants (Fig. 2a, b) grew equally well both in monocultures and mixtures, especially when inoculated with mycorrhiza. Best conditions for growth were observed when inoculated plants of E. camaldulensis were intercropped whereas growth in mixture plots with uninoculated plants proved worst.

The LER results showed differences among treatments. The LERs for height $(F=113.12)$ and diameter $(F=28.02)$ were highly significant $(P \leq 0.01)$ and all LERs were above unity (Tables 1 , 2). LER values for height did not differ among treatments. However, LER values based on diameter differed when both species received the same treatment. If none or both species were inoculated, LER values were higher. On the contrary, if only one of the species was inoculated, LER was reduced. LER values decreased at 20 months in relation to both height and diameter, but never reached less than 1.0 during the course of the experiment.

The double inoculation of A. peregrina also improved dry matter production (Table 3 ) and nutrient content, especially of $\mathrm{N}$ and $\mathrm{P}$ (Table 3 ). The data shown in Table 3 confirm that the productivity of the 


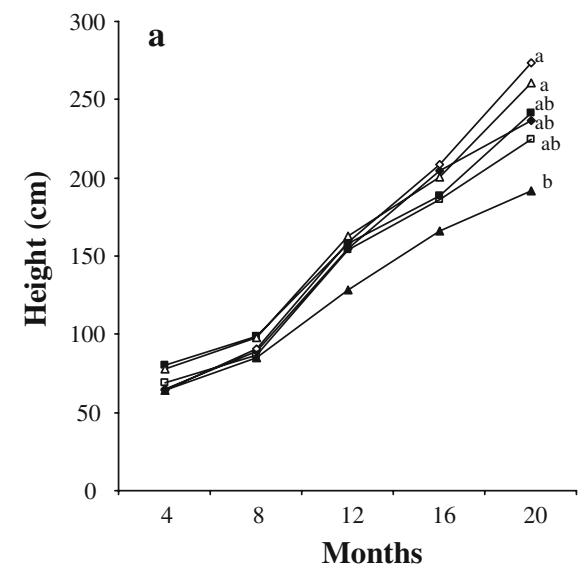

Fig. 1 Effect of intercropping on (a) height and (b) diameter growth of $A$. peregrina under different treatments 20 months after transplantation. Key: $\diamond$, Single plantation of A. peregrina; $\diamond$, single plantation of $A$. peregrina inoculated with Rhizobia and AMF; $\mathbf{\square}$, mixed plantation of A. peregrina + E. camaldulensis + M. urundeuva; $\square$, mixed plantation of A. peregrina $($ Rhizobia $+\mathrm{AMF})+$ E. camaldulensis + M. urundeuva $;$

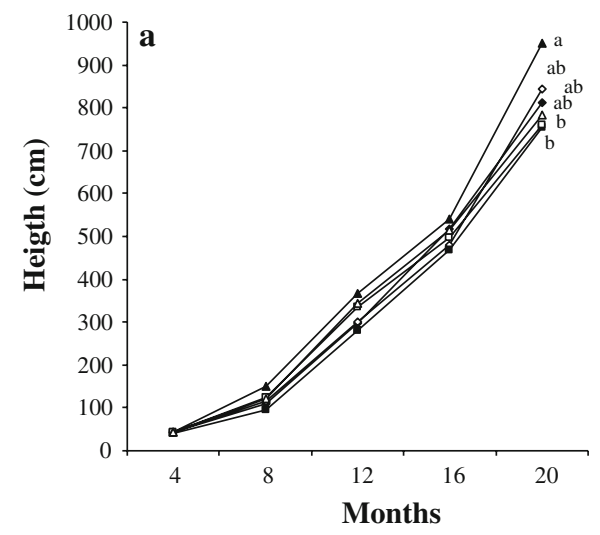

Fig. 2 Effect of intercropping on (a) height and (b) diameter growth of E. camaldulensis under different treatments 20 months after transplantation. Key: $\diamond$, Single plantation of E. camaldulensis, $\diamond$, single plantation of E. camaldulensis + AMF; $\mathbf{\square}$, mixed plantation of A. peregrina + E. camaldulensis + M. urundeuva; $\square$, mixed plantation of A. peregrina (Rhizobia $+\mathrm{AMF})+$ E. camaldulensis +

inoculated stand was greater than that of the uninoculated stands, especially regarding above-ground biomass and basal area. Most of the nutrients were concentrated in the leaves, stem (Table 3), and in the bark (Fig. 3) especially in inoculated plants.

Nutrient concentrations (Table 3) in uninoculated A. peregrina plants followed the order: $\mathrm{N}>\mathrm{K}>$

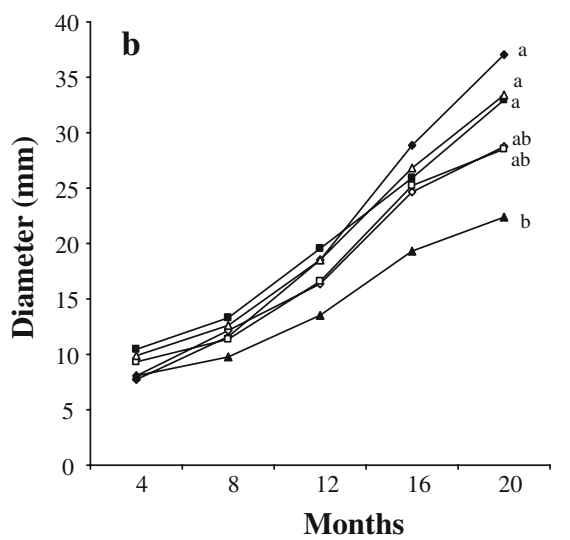

mixed plantation of A. peregrina + E. camaldulensis $(\mathrm{AMF})+M$. urundeuva; $\Delta$, mixed plantation of A. peregrina $($ Rhizobia $+\mathrm{AMF})+$ E. camaldulensis $\quad(\mathrm{AMF})+$ M. urundeuva. Means followed by different letters are significantly different as determined by Tukey multiple-range test at the 5\% confidence level $(P \leq 0.05)$

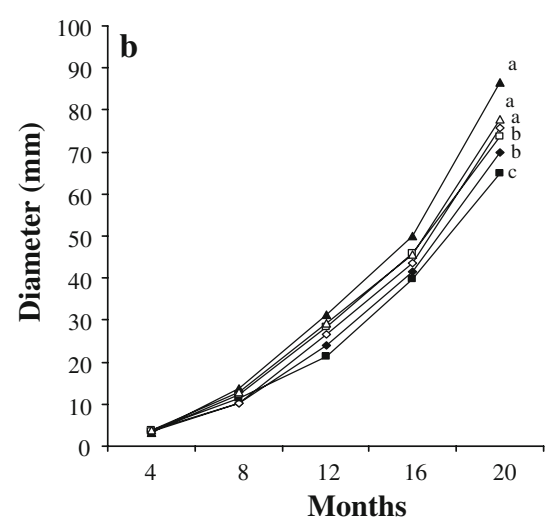

M. urundeuva; $\boldsymbol{\Delta}$, mixed plantation of $A$. peregrina + E. camaldulensis $(\mathrm{AMF})+M$. urundeuva; $\Delta$, Mixed plantation of A. peregrina (Rhizobia $+\mathrm{AMF})+$ E. camaldulensis (AMF) + M. urundeuva. Means with different letters are significantly different as determined by Tukey multiple-range test at the $5 \%$ confidence level $(P \leq 0.05)$

$\mathrm{Ca}>\mathrm{P}>\mathrm{S}>\mathrm{Mg}$, while in inoculated plants the order was: $\mathrm{N}>\mathrm{K}>\mathrm{P}>\mathrm{Ca}>\mathrm{Mg}>\mathrm{S}$.

There was a high number of AMF spores in soil under single and intercropped plantations at 2 years after transplantation (Table 4). Glomeraceae was the dominant family with the genus Glomus, regardless of the treatment (Table 4), followed by Acaulosporaceae. 
Table 1 Land Equivalent Ratio (LER) based on mean height $(\mathrm{cm})$ of single and intercropped, and inoculated (*) and uninoculated plants of A. peregrina and E. camaldulensis, until 20 months after transplantation

Eu, Eucalyptus

camaldulensis; Ap,

Anadenanthera peregrina;

My, Myracrodruon

urundeuva

a Data represent means of 24 plants/block for single plots and 16 plants/block for mixed plots

\begin{tabular}{|c|c|c|c|c|}
\hline Treatments & $\begin{array}{l}\text { Months after } \\
\text { transplanting }\end{array}$ & $\begin{array}{l}\text { Height } \\
(\mathrm{cm}) \mathrm{Ap}\end{array}$ & $\begin{array}{l}\text { Height } \\
(\mathrm{cm}) \mathrm{Eu}\end{array}$ & LER \\
\hline \multirow[t]{3}{*}{$1-\mathrm{Ap}$} & 4 & $64.71^{\mathrm{a}}$ & - & 1.0 \\
\hline & 16 & 155.19 & - & 1.0 \\
\hline & 20 & 273.17 & - & 1.0 \\
\hline \multirow[t]{3}{*}{ 2-Ap* } & 4 & $64.18^{*}$ & - & 1.0 \\
\hline & 16 & $158.83 *$ & - & 1.0 \\
\hline & 20 & $236.83 *$ & - & 1.0 \\
\hline \multirow[t]{3}{*}{ 3-Eu } & 4 & - & 42.12 & 1.0 \\
\hline & 16 & - & 518.7 & 1.0 \\
\hline & 20 & - & 812.0 & 1.0 \\
\hline \multirow[t]{3}{*}{$4-\mathrm{Eu}^{*}$} & 4 & - & $43.34 *$ & 1.0 \\
\hline & 16 & - & $479.7 *$ & 1.0 \\
\hline & 20 & - & $843 *$ & 1.0 \\
\hline \multirow[t]{3}{*}{$5-A p+E u+M y$} & 4 & 80.03 & 39.4 & 2.13 \\
\hline & 16 & 158.28 & 467.5 & 1.92 \\
\hline & 20 & 241.72 & 755 & 1.8 \\
\hline \multirow[t]{3}{*}{$6-\mathrm{Ap}^{*}+\mathrm{Eu}+\mathrm{My}$} & 4 & $69.24 *$ & 42.84 & 2.09 \\
\hline & 16 & $153.74 *$ & 497.4 & 1.91 \\
\hline & 20 & $224.57 *$ & 759 & 1.87 \\
\hline \multirow[t]{3}{*}{$7-\mathrm{Ap}+\mathrm{Eu}^{*}+\mathrm{My}$} & 4 & 64.51 & $44.33^{*}$ & 2.01 \\
\hline & 16 & 128 & $540.1 *$ & 1.94 \\
\hline & 20 & 191.61 & $951 *$ & 1.82 \\
\hline \multirow[t]{3}{*}{ 8-Ap* $+\mathrm{Eu}^{*}+\mathrm{My}$} & 4 & $77.92 *$ & $42.89 *$ & 2.18 \\
\hline & 16 & $162.89 *$ & $513.4 *$ & 2.03 \\
\hline & 20 & $260.97 *$ & $782 *$ & 2.03 \\
\hline
\end{tabular}

preferentially in these plots as well as in mixed plots (Treatment 6) and in the preserved area. On the contrary, Scutellospora cf. coralloidea occurred only in uninoculated plots of A. peregrina and in the disturbed area. Glomus brohultii dominated over all species.

Cluster analysis (Fig. 4) of AM fungal species indicated that the AM communities associated with A. peregrina plants in mixed and uninoculated plots were similar to those of the disturbed area while the composition of AMF species in inoculated plots was closer to those from the preserved forest. The soil from the study area was low in nutrients and organic matter (Table 5). Soil nutrients were improved in general way along the time. The inoculation effect may be observed also in the soil of the experimental area especially in mixed plots, where improvement in organic matter, $\mathrm{CEC}$ and some nutrients $(\mathrm{Ca}, \mathrm{K}$ and $\mathrm{P}$ ) was seen. Content of all nutrients except $\mathrm{P}$ was highest in the soils of the preserved area. Macroporosity was 
Table 2 Land equivalent ratio (LER) based on mean diameter growth $(\mathrm{mm})$ of single and intercropped, and inoculated (*) and uninoculated plants of A. peregrina and E. camaldulensis until 20 months after plantation

$\mathrm{Eu}$, Eucalyptus

camaldulensis; Ap,

My, Myracrodruon

urundeuva

a Data represent means of 24 plants/block for single plots and 16 plants/block for mixed plots
Anadenanthera peregrina;

\begin{tabular}{|c|c|c|c|c|}
\hline Treatments & Months & $\begin{array}{l}\text { Diameter } \\
(\mathrm{mm}) \mathrm{Ap}\end{array}$ & $\begin{array}{l}\text { Diameter } \\
(\mathrm{mm}) \mathrm{Eu}\end{array}$ & LER \\
\hline \multirow[t]{3}{*}{$1-$ Ap } & 4 & $7.7^{\mathrm{a}}$ & - & 1.0 \\
\hline & 16 & 18.5 & - & 1.0 \\
\hline & 20 & 37.1 & - & 1.0 \\
\hline \multirow[t]{3}{*}{ 2-Ap* } & 4 & $8.08 *$ & - & 1.0 \\
\hline & 16 & $16.35^{*}$ & - & 1.0 \\
\hline & 20 & $28.8 *$ & - & 1.0 \\
\hline \multirow[t]{3}{*}{ 3-Eu } & 4 & - & 3.43 & 1.0 \\
\hline & 16 & - & 41.4 & 1.0 \\
\hline & 20 & - & 69.94 & 1.0 \\
\hline \multirow[t]{3}{*}{$4-\mathrm{Eu} *$} & 4 & - & $3.69 *$ & 1.0 \\
\hline & 16 & - & $43.51 *$ & 1.0 \\
\hline & 20 & - & $75.71 *$ & 1.0 \\
\hline \multirow[t]{3}{*}{$5-\mathrm{Ap}+\mathrm{Eu}+\mathrm{My}$} & 4 & 10.46 & 3.7 & 2.43 \\
\hline & 16 & 19.53 & 39.75 & 2.02 \\
\hline & 20 & 33.03 & 65.04 & 1.81 \\
\hline \multirow[t]{3}{*}{$6-\mathrm{Ap}^{*}+\mathrm{Eu}+\mathrm{My}$} & 4 & $9.3^{*}$ & 3.7 & 2.57 \\
\hline & 16 & $16.55^{*}$ & 39.75 & 1.97 \\
\hline & 20 & $28.53 *$ & 65.04 & 1.91 \\
\hline \multirow[t]{3}{*}{$7-\mathrm{Ap}+\mathrm{Eu}^{*}+\mathrm{My}$} & 4 & 8.08 & $12.34 *$ & 2.02 \\
\hline & 16 & 13.56 & $45.85^{*}$ & 1.8 \\
\hline & 20 & 22.4 & $73.62 *$ & 1.57 \\
\hline \multirow[t]{3}{*}{ 8-Ap* $+\mathrm{Eu}^{*}+\mathrm{My}$} & 4 & $9.85^{*}$ & $3.79 *$ & 2.24 \\
\hline & 16 & $18.48^{*}$ & $45.51 *$ & 2.18 \\
\hline & 20 & $32.94 *$ & $77.68 *$ & 2.16 \\
\hline
\end{tabular}

higher in the disturbed than in the preserved area and was reduced in mixed and inoculated plots. In spite of the improvement of organic matter in inoculated plots, soil microporosity was not significantly modified in the experimental area 18 months after transplantation. Soil analysis confirmed the deficiency of $\mathrm{P}$ in the semiarid soils, justifying the inoculation and fertilization treatments that were applied.

\section{Discussion}

The mixed plantation of A. peregrina and E. camaldulensis plants had higher mean height and diameter growth compared with the monocultures, especially in inoculated plots. These results may be attributed to the synergistic action among these species as well as the better nutritional state of the seedlings previously inoculated with rhizobia and/or mycorrhiza fungi in nursery conditions.
Eucalyptus camaldulensis did not show any inhibitory effect on A peregrina growth since plant growth under monocropping systems was equal to that of mixed plots.

According to Huang and Xu (1999) the diameter and height growth of Taxodium ascendens were not depressed in intercropped system. Previous research confirms that mixed plantations may combine the beneficial effects of different species with the additional advantage of product diversification (Montagnini et al. 2003).

The high efficiency of the intercropping systems found in this study as supported by higher total LERs is in agreement with the findings of Baumann et al. (2001), who attributed this phenomenon to the complementary use of resources in plant production allowing an interspecific facilitation. Interspecific facilitation occurs when one crop positively alters the environment of the other, constituting the basis of the yield advantage of intercropping (Lil et al. 1999). 
Table 3 Above-ground biomass and nutrient distribution in inoculated and uninoculated plants of A. peregrine, 2 years after transplantation in single stands in Minas Gerais, Brazil

\begin{tabular}{|c|c|c|c|c|c|c|c|c|}
\hline \multirow[t]{2}{*}{ Plant component } & \multirow{2}{*}{$\begin{array}{l}\text { Basal area } \\
\left(\mathrm{m}^{2} / \mathrm{ha}\right)\end{array}$} & \multirow{2}{*}{$\begin{array}{l}\text { Above-ground } \\
\text { biomass } \\
\left(\mathrm{kg} \mathrm{ha}^{-1}\right) / \%\end{array}$} & \multicolumn{6}{|c|}{ Nutrients in the biomass $\left(\mathrm{Kg} \mathrm{ha}^{-1}\right)$} \\
\hline & & & $\mathrm{N}$ & $\mathrm{P}$ & $\mathrm{K}$ & $\mathrm{Ca}$ & $\mathrm{Mg}$ & $\mathrm{S}$ \\
\hline \multicolumn{9}{|l|}{ Leaves } \\
\hline Uninoculated & & $274.81 * * *(36.3 \%)$ & $11.29 * *$ & $1.66 * * *$ & $9.77 * *$ & $1.55^{\mathrm{NS}}$ & $1.18^{\mathrm{NS}}$ & $1.48 * * *$ \\
\hline Inoculated & & $371.77(32.6 \%)$ & 19.18 & 1.37 & 9.07 & 1.59 & 1.396 & 1.148 \\
\hline \multicolumn{9}{|l|}{ Branches } \\
\hline Uninoculated & & $191.04 * * *(25.2 \%)$ & $17.07 *$ & $0.77 * * *$ & $6.48 * * *$ & $0.48 * * *$ & $0.53 * * *$ & $0.81 * * *$ \\
\hline Inoculated & & $299.57(26.2 \%)$ & 22.11 & 1.11 & 8.0 & 1.22 & 1.22 & 0.66 \\
\hline \multicolumn{9}{|l|}{ Stem } \\
\hline Uninoculated & & $291.06 * *(38.45 \%)$ & $20.0 * *$ & $1.37 * * *$ & $4.55^{* * *}$ & $1.33^{\mathrm{NS}}$ & $0.55^{* * *}$ & $1.29 * * *$ \\
\hline Inoculated & & $467.87(41.06 \%)$ & 29.62 & 1.92 & 5.14 & 1.38 & 0.77 & 1.48 \\
\hline Total (uninoculated) & $813.33( \pm 0.0004)$ & $756.9 * * *$ & $48.36 * * *$ & $3.8 * *$ & $20.8 * *$ & $3.36 * * *$ & $2.26 * * *$ & $3.58 * * *$ \\
\hline Total (inoculated) & $1630.69( \pm 0.082)$ & 1139.21 & 70.91 & 4.40 & 22.21 & 4.19 & 3.38 & 3.28 \\
\hline
\end{tabular}

Analysis of variance and $F$-test. The significance of mean differences between uninoculated and inoculated treatments were detected using the Tukey test, significant at: $* 5 \%, * * 1 \%, * * * 0.1 \%$ and NS, not significant

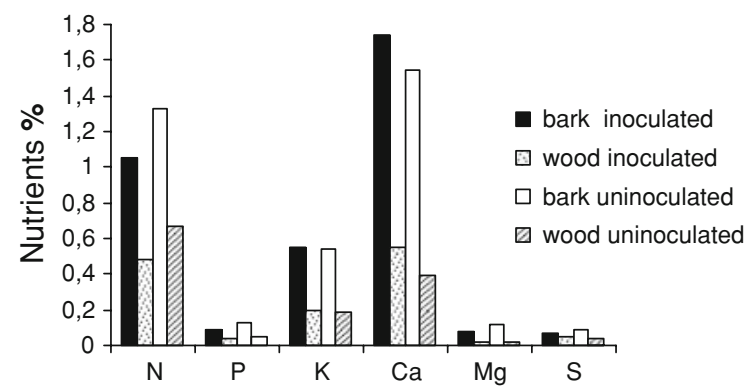

Fig. 3 Percentage of nutrients $(\mathrm{g} / 100 \mathrm{~g})$ in the bark and wood of inoculated and uninoculated plants of A. peregrina at 2 years old in semiarid field conditions in Minas Gerais, Brazil

This facilitation or nurse plant phenomenon (Callaway et al. 1991) has been attributed to leguminous species because of their symbiotic interactions which lead to production of nutrient rich litter, as described for Acacia senegal (Raddad and Luukkanen 2007), Anadenanthera peregrina (Scotti and Correa 2004) and Enterololobium contortisiliquum (Duarte et al. 2006), as well as to the ability of mycorrhizal hyphae to decompose organic matter (Scotti and Correa 2004) and improve soil nutrient availability (Smith and Read 1997). Therefore, the hypothesis of higher availability of soil nutrients is in agreement with the fact that double inoculation favoured the synergisms among plants of A. peregrina and E. camaldulensis. If soil nutrients are available synergism is favoured. Indeed, the inoculation of only one species resulted in lower growth of uninoculated species and in the decrease of LER data, in contrast with the plots where both species were inoculated. Increase in organic matter and soil nutrients with time, in mixed plots with inoculated plants, also supports this hypothesis.

The advantage of inoculation in plant synergism was reinforced by the results showing improvement in dry matter and nutrient content of inoculated A. peregrina plants, especially total $\mathrm{N}$ content, which may be attributed to nitrogen fixation. These results confirm the efficiency of the inoculated strain BHCB-A10. These nutrients were accumulated in the leaves stem and bark, which may be considered important sources of nutrient for the litter compartment and nutrient cycling in the forestry systems. Elemental concentrations of non-inoculated $A$. peregrina plants showed a similar profile $(\mathrm{N}>\mathrm{K}>\mathrm{Ca}>\mathrm{P}>\mathrm{S}>\mathrm{Mg}$ ) to that described for Acacia mearnsii $(\mathrm{N}>\mathrm{K}>\mathrm{Ca}>\mathrm{P}>$ $\mathrm{S}>\mathrm{Mg}$ ) by Caldeira et al. (2002), differing from inoculated $A$. peregrina plants, where $\mathrm{P}$ concentration was higher. The increased phosphorus concentration observed in inoculated plants seems to be linked to the mycorrhiza effect.

Glomeraceae was the dominant mycorrhizal family in all the studied plots. High spore density has been considered a form of selective adaptation to the 
Table 4 Spore abundance (per $100 \mathrm{~g}$ soil) of AMF species in the homogeneous and mixed-plantations of A. peregrina and E. camaldulensis at Jaíba, Minas Gerais, Brazil

\begin{tabular}{|c|c|c|c|c|c|c|c|c|}
\hline \multirow[t]{2}{*}{ AMF species } & \multicolumn{8}{|c|}{ Spore abundance } \\
\hline & 1 & 2 & 3 & 4 & 5 & 6 & $\mathrm{P}$ & $\mathrm{C}$ \\
\hline \multicolumn{9}{|l|}{ Gigasporaceae } \\
\hline Gigaspora margarita Becker \& Hall & $25^{\mathrm{a}}$ & 27.5 & 0 & 0 & 1.25 & 12 & 15 & 2.5 \\
\hline Gigaspora rosea Nicolson \& Schenck & 0 & 6.25 & 0 & 0 & 0 & 1.25 & 0 & 6.16 \\
\hline Scutellospora cerradensis Spain \& Miranda & 0 & 1.25 & 0 & 0 & 0 & 1.25 & 1.25 & 0 \\
\hline $\begin{array}{l}\text { Scutellospora cf coralloidea (Trappe, Gerd. \& Ho) } \\
\text { Walker \& Sanders }\end{array}$ & 8.75 & 0 & 0 & 0 & 0 & 0 & 0 & 14.2 \\
\hline \multicolumn{9}{|l|}{ Acaulosporaceae } \\
\hline Acaulospora bireticulata Rothwell \& Trappe & 0 & 0 & 5 & 6.25 & 1.25 & 2.5 & 8.5 & 15.6 \\
\hline A. delicata Walker, Pfeiffer \& Bloss & 8.75 & 1.25 & 0 & 0 & 0 & 2.5 & 1.25 & 0 \\
\hline A. laevis Gerdemann \& Trappe & 6.25 & 7.5 & 5 & 6.25 & 0 & 7.5 & 0 & 0 \\
\hline A. mellea Spain \& Schenck & 3.75 & 0 & 0 & 0 & 0 & 0 & 0 & 0 \\
\hline A. scrobiculata Trappe & 8.75 & 5 & 6.25 & 21.25 & 15 & 10.5 & 28.5 & 80 \\
\hline Acaulospora sp. 1 & 0 & 0.62 & 1.25 & 1.25 & 0 & 1.25 & 0 & 0 \\
\hline \multicolumn{9}{|l|}{ Glomeraceae } \\
\hline Glomus brohultii Sieverd. \& Herrera & 53.75 & 96.25 & 117.5 & 201.25 & 240 & 106 & 120 & 212.5 \\
\hline Total spore number $(\mathrm{N})$ & 115 & 145.62 & 135 & 236.25 & 257 & 144.75 & 174.5 & 330.96 \\
\hline
\end{tabular}

Treatments: 1, monoculture of A. peregrina; 2, monoculture of A. peregrina + rhizobia and AMF; 3, monoculture of E. camaldulensis; 4, monoculture of E. camaldulensis $+\mathrm{AMF} ; 5$, mixed plantation of A. peregrina + E. camaldulensis + M. urundeuva; 6, mixed plantation of A. peregrina (Rhizobia $+\mathrm{AMF})+$ E. camaldulensis $(\mathrm{AMF})+$ M. urundeuva; $\mathrm{P}$, preserved area of woody caatinga and $\mathrm{C}$, disturbed vegetation

${ }^{a}$ Values represent the mean of three samples taken from the pooled soil samples from each treatment area

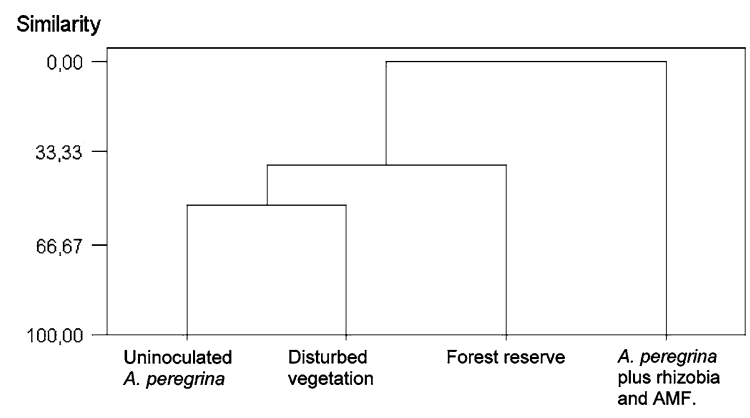

Fig. 4 Complete link cluster analysis based on similarities of Arbuscular mycorrhizal fungi (AMF) species composition of four sampling sites in Minas Gerais, Brazil (1, A. peregrina monoculture; 2, A. peregrina monoculture inoculated with Rhizobium + AMF; 3, disturbed vegetation: Carrasco and 4, preserved area of woody Caatinga)

hot and arid ecosystem (Tao and Zhiwei 2005) and has not been correlated with infectivity related to low $\mathrm{P}$ concentration in soil and with AMF species in the rhizosphere (Jasper et al. 2005).

The profile of AMF species in the rhizosphere of inoculated A. peregrina plants in the mixed plot was similar to that of the preserved area. This suggests a selective and synergistic effect of plant species. This idea is reinforced by the fact that E. camaldulensis plants and disturbed invasive vegetation favoured the Acaulosporaceae family in comparison to the Gigasporaceae species which was increased in the preserved area. Therefore, the cultivated species modified the distribution of AMF families in favour of some fungi species such as A. bireticulata, A. laevis, A. scrobiculata and $G$. brohultii. Such selective ability to modify the AMF species can be understood in the light of differences among plant exudates (Whitelaw 2000) which elicit a root zone effect, resulting in a stimulatory effect of both symbiotic and non-symbiotic microorganisms (Ishii et al. 1997). The greatest number of AMF spores in the inoculated E. camaldulensis rhizosphere as well as in the disturbed vegetation may be related to the fast growing characteristics of E. camaldulensis and the pioneer species of disturbed vegetation, which require more available nutrients for their development. The rhizosphere effect determines a selective pressure on the 


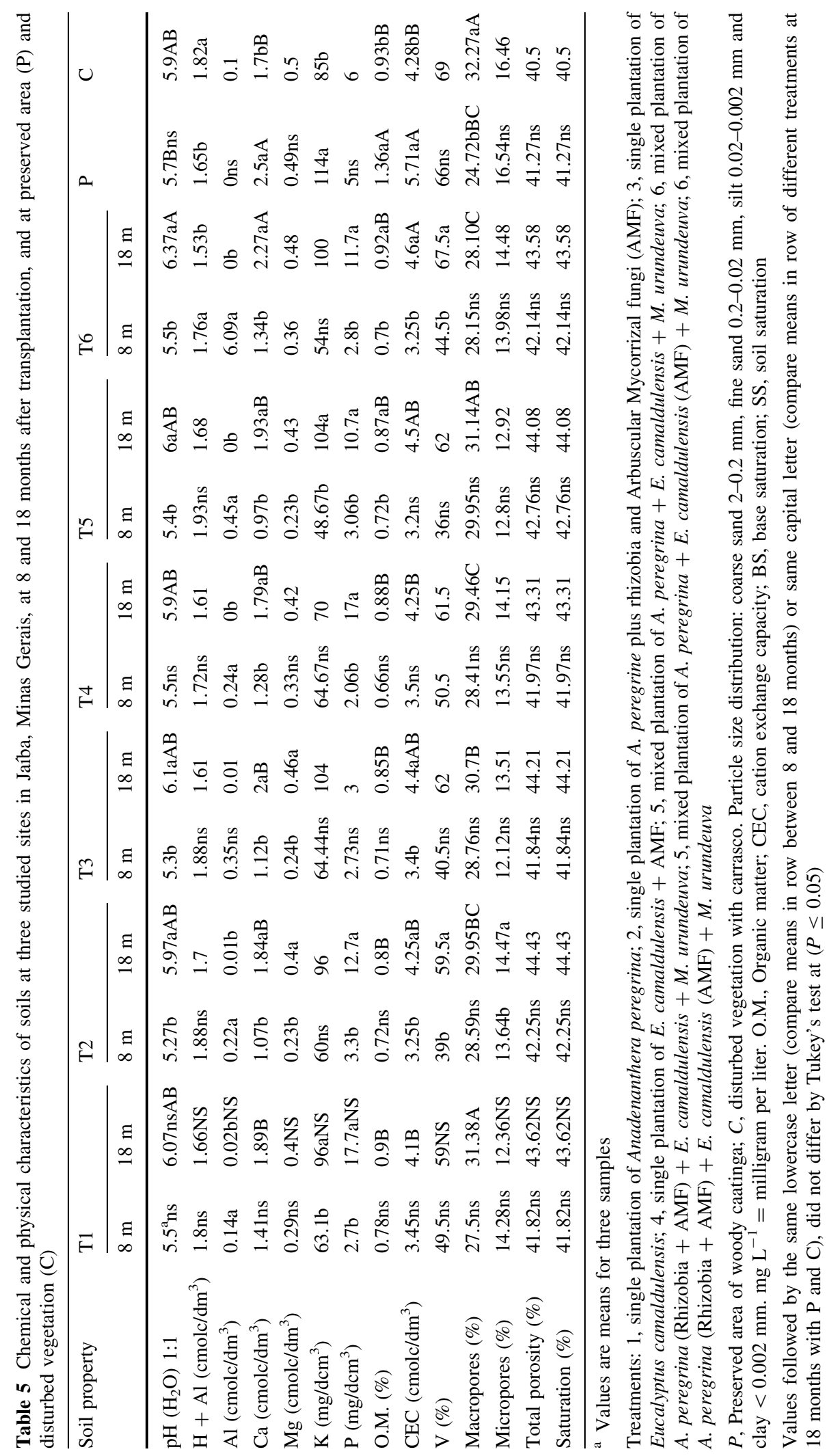


mycorrhizal population, therefore, more competitive species like $G$. brohultii were favoured in inoculated and uninoculated plants.

Other AMF species such as Scutellospora cf. collaroidea were naturally selected by A. peregrina rhizosphere in the uninoculated stands and in the soil of disturbed vegetation, supporting the rhizosphere effect. Therefore, we can assume a higher rhizosphere effect in mixed plantation which results in greater biological diversity of AMF species. This greater biological diversity of plants and microorganisms in mixed plots where both E. camaldulensis and A. peregrina were inoculated allows a greater biological activity which may explain the improvement of soil organic matter and soil nutrients. The increase of soil organic matter not only reduced soil macroporosity but also improved soil nutrient availability, what result in a higher plant growth and in LER results. Thus, in intercropping systems the rhizospheric effect may be able to modify the soil environment of the plants resulting in an interspecific facilitation.

\section{Conclusions}

The growth of $A$. peregrina was not inhibited by the presence E. camaldulensis plants when both species received the same inoculation treatment but it was when uninoculated A. peregrina plants were intercropped with inoculated $E$. camaldulensis, confirming the importance of double inoculation for the synergistic interaction among intercropped plants of these species. The AMF inoculation increased the phosphorus content of A. peregrina plants and altered the distribution profile of rhizosphere AMF species, so that was similar to that in a preserved forest area. Following from these conclusions, it is recommended that all component species in intercropped tree mixtures are inoculated, to guarantee improvements in height and diameter growth from inoculation as well as benefits for nutrient cycling, soil organic matter and the reduction of soil macroporosity. This intercropping system is suitable for agroforestry in marginal or degraded lands and may be of great potential in semiarid degraded areas.

Acknowledgements This research was supported by the Ministry of Environment: National Found of Environment (FNMA/MMA). The authors are grateful to Conselho Nacional de Pesquisa (CNPq) and Coordenação de Aperfeiçoamento de Pessoal de Nível Superior (CAPES) for scholarships granted to Maria Rita Scotti and Marcela C. Pagano. We would also like to thank Empresa de Pesquisa Agropecuária de Minas Gerais (EPAMIG)-Mocambinho for technical support.

\section{References}

Baumann DT, Bastiaans L, Kropff MJ (2001) Competition and crop performance in a leek-celery intercropping system. Crop Sci 41:764-774

Caldeira MV, Schumacher MV, Spathelf P (2002) Quantification of nutrient content in above-ground biomass of young Acacia mearnsii De Wild., provenance Bodalla. Ann Sci 59:833-838. doi:10.1051/forest:2002081

Callaway RM, Nadkarni NM, Mahall BE (1991) Facilitation and interference of Quercus douglasii on understory productivity in Central California. Ecology 72:14841499. doi:10.2307/1941122

Duarte NF, Bucek EU, Karam D, Sá N, Scotti MRM (2006) Mixed field plantation of native and exotic species in semi-arid Brazil. Aust J Bot 54:755-764. doi:10.1071/ BT05173

Empresa Brasileira de Pesquisa Agropecuaria-EMBRAPA (1979) Manual de Análises Químicas de solos. Plantas e fertilizantes, Brasília

Gerdemann JW, Nicolson TH (1963) Spores of mycorrhizal Endogone species extracted from soil by wet sieving and decanting. Trans Br Mycol Soc 84:679-684

Ghosh PK (2004) Growth, yield, competition and economics of groundnut/cereal fodder intercropping systems in the semi-arid tropics of India. Field Crops Res 88:227-237. doi:10.1016/j.fcr.2004.01.015

Hodge A, Campbell CD, Fitter AH (2001) An arbuscular mycorrhizal fungus accelerates decomposition and acquires nitrogen directly from organic material. Nature 413:297-299. doi:10.1038/35095041

Huang W, Xu Q (1999) Overyield of taxodium ascendensintercrop systems. For Ecol Manage 116:33-38

Ishii T, Narutaki A, Sawada K et al (1997) Growth stimulatory substances for vesicular-arbuscular mycorrhizal fungi in Bahia grass (Paspalum notatum Flügge.) roots. Plant Soil 196:301-307. doi:10.1023/A:1004232309393

Jasper DA, Robson AD, Abbott LK (2005) Revegetation in an iron ore mine-nutrient requeriments for plant growth and potential role of vesicular arbuscular (VA) mycorrhizal fungi. Aust J Soil Res 26:497-507. doi:10.1071/SR988 0497

Lil L, Yang S, Li X, Zhang F, Christie P (1999) Interspecific complementary and competitive interactions between intercropped maize and faba bean. Plant Soil 212:105-114. doi:10.1023/A:1004656205144

Marques MS, Pagano MC, Scotti MRM (2001) Dual inoculation of woody legume (Centrolobium tomentosum) with rhizobia and mycorrhizal fungi in southeastern Brazil. Agrofor Syst 52:107-117. doi:10.1023/A:1010637401475

Marques MS, Sá NMH, Scotti MRM (2003) Decomposition, inorganic elements dynamic and microbial colonization of araribá (Centrolobium tomentosum Guill. ex Benth) leaves 
on latosols of Brazilian Atlantic forest. Agricult Tec 63:59-68

May FE, Ash JE (1990) An assessment for the allelopathic potential of Eucalyptus. Aust J Bot 38:245-254. doi: 10.1071/BT9900245

May BM, Attiwill PM (2003) Nitrogen-fixation by Acacia dealbata and changes in soil properties 5 years after mechanical disturbance or slash-burning following timber harvest. For Ecol Manage 18:339-355

Mead R, Willey RW (1980) The concept of a land equivalent ratio and advantages in yields from intercropping. Exp Agric 16:217-228

Montagnini F, Ugalde L, Navarro C (2003) Growth characteristics of some native tree species used in silvopastoral systems in the humid lowlands of Costa Rica. Agrofor Syst 59:163-170. doi:10.1023/A:1026351812036

Raddad EY, Luukkanen O (2007) The influence of different Acacia senegal agroforestry systems on soil water and crop yields in clay soils of the Blue Nile region, Sudan. Agric Water Manage 87:61-72. doi:10.1016/j.agwat. 2006.06.001

Rao MR, Nair PKR, Ong CK (1997) Biophysical interactions in tropical agroforestry systems. Agrofor Syst 38:3-50. doi:10.1023/A:1005971525590

Ritz K, Young IM (2004) Interactions between soil structure and fungi. Mycologist 18:52-59. doi:10.1017/S0269915X 04002010

Rizzini CT (1997) Tratado de fitogeografia do Brasil. Âmbito cultural, São Paulo
Santiago GM, Garcia QS, Scotti MRM (2002) Effect of postplanting inoculation with Bradyrhizobium sp. and mycorrhizal fungi on the growth of Brazilian rosewood, Dalbergia nigra Allem. ex Benth, in two tropical soils. New For 24:15-25. doi:10.1023/A:1020508311851

Schenk NC, Perez Y (1988) Manual for the identification of VA mycorrhizal fungi. INVAM, University of Florida, Gainsville, FLA

Scotti MRM, Correa EJA (2004) Growth and litter decomposition of woody species inoculated with rhizobia and arbuscular mycorrhizal fungi in semiarid Brazil. Ann Sci 61:87-95. doi:10.1051/forest:2003088

Smith SE, Read DJ (1997) Mycorrhizal symbiosis, 2nd edn. Academic Press, London

Somasegaran P, Hoben HJ (1985) Methods in legumeRhizobium technology. NIFTAL, Hawaii

Tao L, Zhiwei Z (2005) Arbuscular mycorrhiza in hot and arid ecosystem in southwest China. Appl Soil Ecol 29:135141. doi:10.1016/j.apsoil.2004.11.005

Vandermeer J (1989) The ecology of intercropping. Cambridge University Press, Cambridge, UK

Walker C, Mize W, McNabb HS (1982) Populations of endogonaceus fungi at two populations in central Iowa. Can J Bot 60:2518-2529. doi:10.1139/b82-305

Whitelaw MA (2000) Growth promotion of plants inoculated with phosphate-solubilizing fungi. Adv Agron 69:99-151. doi:10.1016/S0065-2113(08)60948-7 